\section{SANKSI ATAS PELANGGARAN IJIN TINGGAL WARGA NEGARA ASING MENURUT UNDANG- UNDANG NO. 6 TAHUN 2011 TENTANG KEIMIGRASIAN ${ }^{1}$ \\ Oleh: Kennisa Monoarfa ${ }^{2}$ Harold Anis $^{3}$ \\ Thor Bangsaradja Sinaga ${ }^{4}$}

\begin{abstract}
ABSTRAK
Tujuan dilakukannya peneltian ini adalah untuk mengetahui bagaimana Ketentuan Tentang Ijin Tinggal Warga Negara Asing Menurut Undang-Undang No. 6 Tahun 2011 Tentang Keimigrasian dan bagaimana Penerapan Sanksi Atas Pelanggaran ljin Tinggal Warga Negara Asing. Dengan menggunakan metode peneltian yuridis normatif,
\end{abstract} disimpulkan: 1. Berkaitan dengan ketentuan tentang ijin tinggal Warga Negara Asing, pada prinsipnya keberadaan orang asing $\mathrm{di}$ Indonesia tetap dibatasi dalam hal kebaradaan dan kegiatannya. Hal ini dapat dilihat dalam berbagai instrumen, perizinan di bidang keimigrasian, sebagaimana ditentukan dalam UU Keimigrasian No. 6 Tahun 2011 yang mengatur mengenai beberapa jenis perizinan bagi Orang Asing di Indonesia. Pada dasarnya setiap orang asing yang berada di Indonesia wajib memiliki izin tinggal yang masih berlaku, dan ijin ini diberikan sepanjang memenuhi persyaratan keimigrasian. ljin Tinggal diberikan kepada orang asing oleh Pejabat Imigrasi atau pejabat dinas luar negeri untuk berada di Wilayah Indonesia. ljin tersebut terdiri atas, liin Tinggal diplomatik, ljin Tinggal dinas, ljin Tinggal kunjungan, ljin Tinggal terbatas dan ljin Tinggal tetap. 2. Bahwa tidak semua tindak pidana keimigrasian, khususnya pelanggaran ijin tinggal (overstay), dan tidak memiliki izin tinggal (illegal stay) warga negara asing dapat diterapkan sanksi pidana, karena di dalam Undang-undang Nomor 6 Tahun 2011 tentang Keimigrasian dimungkinkan diterapkan tindakan keimigrasian yang bersifat administratif non penal. Namun apabila tetap diproses melalui jalur hukum dan diterapkan sanksi pidana terhadap pelakunya, hal ini

\footnotetext{
${ }^{1}$ Artikel Skripsi

2 Mahasiswa pada Fakultas Hukum Unsrat, NIM : 15071101487

${ }^{3}$ Fakultas Hukum Unsrat, Magister IImu Hukum

${ }^{4}$ Fakultas Hukum Unsrat, Magister IImu Hukum
}

merupakan fungsi hukum pidana sebagai ultimum remedium dan sifatnya kasuistis. Tindakan administratif yang dapat diterapkan dibagi menjadi beberapa jenis, diantaranya pencantuman dalam daftar pencegahan atau penangkalan, pembatasan, perubahan, atau pembatalan izin tinggal, larangan untuk berada di satu atau beberapa tempat tertentu di wilayah Indonesia, keharusan untuk bertempat tinggal di suatu tempat tertentu di wilayah Indonesia, pengenaan biaya beban, dan deportasi dari wilayah Indonesia (Pasal 75 Ayat 2 Undang-Undang Nomor 6 Tahun 2011).

Kata kunci: Sanksi, Pelanggaran ljin Tinggal, Warga Negara Asing, Keimigrasian

\section{PENDAHULUAN}

\section{A. Latar Belakang Masalah}

Pada prinsipnya orang asing bahkan yang merupakan penduduk Indonesia mempunyai hak dan kewajiban yang berbeda dengan hak dan kewajiban warga negara Indonesia. Terhadap orang asing dikenakan sejumlah pembatasan tertentu, khususnya yang menyangkut masalah hak. Berdasarkan ketentuan UndangUndang Keimigrasian 1992, setiap orang asing dapat dibatasi ruang geraknya, bahkan dapat dideportasi, atau dipersona non-grata, atau diserahkan kepada negara lain, terutama apabila melakukan tindak pidana. Berbeda dari yang berstatus penduduk Indonesia (yang mempunyai hak untuk keluar dan masuk Indonesia) setiap orang asing hanya berhak keluar dari Indonesia.

Pelanggaran dan kejahatan keimigrasian akan timbul dengan datangnya orang asing di wilayah Indonesia. Termasuk juga di Kota Manado Provinsi Sulawesi Utara, Pelanggaran yang dilakukan orang asing berupa melebihi batas waktu izin tinggal (overstay) adalah salah satu pelanggaran yang sering dilakukan. Orang asing yang tidak menghormati atau menaati peraturan peundang-undangan dapat dikenakan tindakan administratif keimigrasian. Menyikapi akan hal tersebut terhadap pelanggaran yang dilakukan oleh orang asing akan diambil tindakan tegas. Tindakan keimigrasian yang dikenakan dapat berupa deportasi sebagai salah satu tindakan khusus dan khas dari fungsi keimigrasian.

Imigrasi adalah Lembaga Negara yang vital 
bagi lalu lintas perpindahan penduduk antar Negara. Bagir Manan, berpendapat bahwa fungsi keimigrasian merupakan fungsi penyelenggaraan administrasi negara atau penyelenggaraan administrasi pemerintahan. Oleh karena itu sebagai bagian dari penyelenggaraan kekuasaan eksekutif yaitu fungsi administrasi negara dan pemerintahan, maka hukum keimigrasian dapat dikatakan bagian dari bidang Hukum Administrasi Negara. ${ }^{5}$

Petugas imigrasi dalam rangka mempertahankan dan melaksanakan tugas untuk mengawasi kedatangan dan keberangkatan dari warga / orang untuk melihat dan memvalidasi identitas orang yang akan bepergian ke luar negeri juga memiliki tugas untuk mengawasi orang orang yang datang dari luar negeri, dimana tugas imigrasi antara lain untuk juga melihat dan mengidentifikasi kedatangan orang asing. Lokasi Anggota imigrasi itu sendiri, antara lain: Bandara Internasional, International Pelabuhan Laut dan Perbatasan Negara untuk mempertahankan, mengawasi, dan memperhatikan kedatangan dan keberangkatan orang atau barang yang datang dan pergi dari satu negara atau lainnya negara.

Berdasarkan uraian latar belakang diatas, maka penulis tertarik untuk membuat karya tulis ilmiah yang berbentuk sripsi dengan judul : "Sanksi Atas Pelanggaran Izin Tinggal Warga Negara Asing Menurut UU No 6 Tahun 2011 Tentang Keimigrasian".

\section{B. Perumusan Masalah}

1. Bagaimanakah Ketentuan Tentang Ijin Tinggal Warga Negara Asing Menurut Undang-Undang No. 6 Tahun 2011 Tentang Keimigrasian?

2. Bagaimanakah Penerapan Sanksi Atas Pelanggaran ljin Tinggal Warga Negara Asing?

\section{Metode Penelitian}

Secara umum, ruang lingkup penelitian ini merupakan disiplin ilmu hukum, yakni Hukum Keimigrasian khususnya berkaitan dengan ketentuan yang mengatur tentang Izin Tinggal

\footnotetext{
5 Bagir Manan, "Hukum Keimigrasian dalam Sistem Hukum Nasional", disampaikan dalam Rapat Kerja Nasional Keimigrasian, Jakarta, 14 Januari 2000, hlm. 7.
}

Warga Negara Asing sebagaimana yang diatur dalam Undang-Undang No. 6 Tahun 2011 Tentang Keimigrasian, maka penelitian ini merupakan bagian dari penelitian hukum yakni dengan cara meneliti bahan pustaka yang dinamakan penelitian hukum kepustakaan. Sedangkan metode pendekatan yang digunakan dalam penelitian ini adalah yuridis normatif, yaitu penelitian yang difokuskan untuk mengkaji penerapan kaidah-kaidah atau norma-norma dalam hukum normatif.

\section{PEMBAHASAN}

\section{A. Ketentuan Tentang ljin Tinggal Warga Negara Asing Menurut Undang-Undang Nomor 6 Tahun 2011 Tentang Keimigrasian \\ 1. Ketentuan Tentang Orang Asing Yang Masuk Wilayah Indonesia}

Setiap orang yang masuk atau keluar wilayah Indonesia harus melalui prosedur yang berlaku, dalam hal ini sesuai dengan UndangUndang Nomor 6 Tahun 2011 Tentang Keimigrasian, dan khusus bagi warga negara asing berikut penjelasan singkat mengenai pengaturan keluar masuk wilayah Indonesia.

Pengawasan terhadap orang asing berdasarkan Pasal 68 UU Keimigrasian dilaksanakan dalam bentuk dan cara, sebagai berikut:

1. Pengumpulan dan pengolahan data orang asing yang masuk atau keluar wilayah Indonesia;

2. Pendaftaran orang asing yang berada di wilayah Indonesia;

3. Pemantauan, pengumpulan dan pengolahan bahan keterangan serta informasi mengenai kegiatan orang asing;

4. Penyusunan daftar nama-nama orang asing yang tidak dikehendaki masuk atau keluar wilayah Indonesia; dan

5. Kegiatan lainnya.

Izin yang diberikan terhadap warga negara asing untuk berada di wilayah Indonesia disebut dengan Izin Tinggal. Izin tinggal diberikan terhadap warga negara asing sesuai visa yang mereka miliki. Izin tinggal bagi warga negara asing di wilayah Indonesia dibatasi oleh jangka waktu tertentu. Izin tinggal yang diperoleh oleh WNA tersebut digunakan untuk melakukan kegiatan di Indonesia. Izin tinggal itu diberikan untuk melaksanakan komitmen internasional di bidang keimigrasian, baik 
untuk wisata, Tenaga Kerja Asing, investor, dan kerja sama di bidang pendidikan serta perkembangan globalisasi. Hal ini dilakukan dimana masing-masing negara di dunia memberikan kemudahan-kemudahan maupun berdasarkan asas resiprositas. ${ }^{6}$

\section{Ketentuan Tentang ljin Tinggal}

Bagir Manan menyebutkan bahwa izin merupakan suatu persetujuan dari penguasa berdasarkan peraturan perundang - undangan untuk memperbolehkan melakukan tindakan atau perbuatan tertentu yang secara umum dilarang. ${ }^{7}$

Izin tinggal adalah izin yang diberikan kepada orang asing oleh Pejabat Imigrasi atau pejabat dinas luar negeri untuk berada di wilayah Indonesia (UU No. 6 tahun 2011 tentang Keimigrasian Pasal 1 ayat 21)

Tindakan keimigrasian biasanya dilakukan apabila terjadi penyalahgunaan izin tinggal yang dilakukan oleh warga Negara asing yang tinggal di wilayah Republik indonesia. Oleh karena itu setiap Orang Asing yang berada di wilayah Indonesia wajib memiliki Izin Tinggal (Pasal 48 UU No.6 Tahun 2011 Tentang Keimigrasian).

Dibidang keimigrasian dikenal beberapa jenis perizinan, antara lain sebagai berikut: ${ }^{9}$

a. Izin Tinggal, adalah izin yang diberikan kepada orang asing oleh pejabt imigrasi atau pejabat dinas luar negeri untuk berada di wilayah Indonesia.

b. Izin Masuk Kembali, adalah izin tertulis yang diberikan oleh pejabat imigrasi kepada orang asing pemegang izin tinggal terbatas dan izin tinggal tetap untuk masuk kembali ke wilayah Indonesia.

Izin Tinggal terdiri atas:

a. Izin Tinggal Diplomatik, diberikan kepada Orang Asing yang masuk ke wilayah Indonesia dengan Visa Diplomatik.

\footnotetext{
6 Sihar Sihombing, Hukum Imigrasi, Nuansa Mulia, Bandung, 2009, hlm. 60.

7 Bagir Manan, 1995, Ketentuan - Ketentuan Mengenai Pengaturan Penyelengaraan Hak Kemerdekaan Berkumpul Ditinjau Dari Perspektif UUd 1945, Makalah, Tidak dipublikasikan, Jakarata, hal.8

8 Lihat, UU No. 11 Tahun 2006

9 Jazim Hamidi dan Charles Christian, Hukum Keimigrasian Bagi Orang Asing Di Indonesia, Jakarta, Sinar Grafika, 2015, hal. 45
}

b. Izin Tinggal Dinas, diberika kepada Orang Asing yang masuk ke wilayah Indonesia dengan Visa Dinas.

c. Izin Tinggal Kunjungan, diberikan kepada Orang Asing yang masuk ke wilayah Indonesia dengan Visa Kunjungan, atau anak yang baru lahir di wilayah Indonesia dan pada saat lahir ayah dan/atau ibunya pemegang Izin Tinggal Kunjungan.

d. Izin Tinggal Terbatas, diberikan kepada Orang Asing yang masuk ke wilayah Indonesia dengan Visa Tinggal Terbatas; anak yang pada saat lahir di wilayah Indonesia Ayah dan/atau Ibunya pemegan izin tinggal terbatas; orang asing yang diberika alih status dari izin tinggal kunjungan; nahkoda, awak kapal, atau tenaga ahli asing diatas kapal laut, alat apung, atau instalasi yang beroperasi di wilayah perairan dan wilayah yurisdiksi Indonesia sesuai dengan ketentuan perundang- undangan; orang asing yang kawin secara sah dengan warga negara Indonesia; atau anak dari orang asing yang kawin secara sah dengan warga negara Indonesia.

e. Izin Tinggal Tetap, dapat diberikan kepada orang asing pemegang izin tinggal terbatas sebagai rohaniawan, pekerja, insvestor, dan lanjut usia keluarga karena perkawinan campuran; suami, istri, dan/atau anak dari orang asing pemegang izin tinggak tetap; orang asing eks warga negara Indonesia dan eks subjek anak kewarganegaraan ganda Republik Indonesia.

Selain izin tinggal, ada beberapa istilah yang memiliki defenisi terkait dengan perizinan, yaitu Visa Republik Indonesia adalah keterangan tertulis yang diberikan oleh pejabat yang berwenang di perwakilan Republik Indonesia atau di tempat lain yang ditetapkan oleh pemerintah Indonesia yang memuat persetujuan bagi orang asing untuk melakukan perjalanan ke wilyah Indonesia dan menjadi dasar untuk pemberian Izin Tinggal.

Izin Keimigrasian adalah bukti keberadaan yang sah bagi setiap orang asing diwilayah Indonesia. Izin keimigrasian terdiri dari:

a. Izin Tinggal Kunjungan

Izin tinggal kunjungan adalah izin tinggal untuk tugas-tugas pemerintah, kegiatan sosial budaya, atau usaha. Sesuai dengan 
ketentuan Pasal 50 ayat (1) UU Keimigrasian dikatakan bahwa izin kunjungan diberikan kepada orang asing yang masuk wilyah Indonesia dengan visa kujungan atau anak baru lahir di wilayah Indonesia dana pada saat lahir ayah dan/atau ibu pemegang izin tinggal kunjungan. Berdasarkan Pasal 38 UU Keimigrasian disebutkan bahwa visa kunjungan diberika kepada orang asing yang melakukan perjalanan ke Indonesia dalam rangka tugas pemerintah, pendidikan, sosial budaya, pariwisata, bisnis, keluarga, jurnalistik, atau singgah untuk meneruskan perjalanan ke negara lain.

Kegiatan sosial budaya yang dimaksud disini adalah misi kesenian, pendidikan atau tukar-menukar budaya. Waktu izin kunjungan paling lama 60 hari, terhitung sejak tanggal diberikannya izin masuk wilayah Negara Republik Indonesia. Izin kunjungan ini dapat diperpanjang paling banyak 5 kali berturut-turut. Setiap perpanjangan masing-masing 30 hari, kecuali untuk izin kunjungan wisata tidak dapat diperpanjang.

Pertimbangan pemberian kebijakan tersebut adalah didasarkan pada asas timbal balik atau resiprositas, asas mamfaat, saling menguntungkan, dan tidak menimbulkan gangguan keamanan. Pemberian izin kunjungan singkat ini diberikan dengan ketentuan berikut:

1. Lamanya izin kunjungan bebas visa 30 hari.

2. Tidak dapat dialihkan atau diubah menjadi izin keimigrasiam yang lainnyatidak dapat diperpanjang, kecuali dalam hal terjadi bencana alam, kecelakaan atau sakit, dapat diperpanjang setelah mendapatkan persetujuan dari Menteri.

b. Izin Tinggal Terbatas

Izin tinggal terbatas adalah izin yang diberikan kepada orang asing yang memenuhi persyaratan keimigrasian serta syarat-syarat lain yang diatur dengan peraturan pemerintah. Izin keimigrasian mengenai tinggal terbatas sesuai dengan namanya diberikan dengan waktu terbatas.
Izin tinggal terbatas bagi orang asing dapat gugur karena:

1. Melepaskan hak izin tinggal terbatasnya.

2. Atas kemauan sendiri.

3. Berada di luar wilayah Indonesia dan telah melebihi waktu izin masuk kembali ke wilayah Negara Republik Indonesia.

4. Dikarenakan tindakan keimigrasian.

c. Izin Tinggal Tetap

Izin ini diberikan kepada orang asing untuk tinggal di wilayah Negara Republik Indonesia sepanjang memenuhi persyaratan keimigrasian. Izin tinggal tetap ini berlaku selama 5 Tahun sekali selama yang bersangkutan masih menetap di wilayah Negara Republik Indonesia.

Sesuai dengan Pasal 159 ayat (4) Peraturan Pemerintah Nomor 31 Tahun 2013 tentang Peraturan Pelaksana UU Keimigrasian, izin tinggal tetap bagi orang asing dapat dibatalkan karena yang bersangkutan:

1. Terbukti melakukan tindak pidana terhadap negara sebagaimana diatur dalam peraturan perundang-undangan.

2. Melakukan kegiatan yang membahayakan keamanan negara atau patut diduga akan membahayakan bagi keamanan dan ketertiban umum. Melanggar pernyataan integrasi. Mempekerjakan tenaga kerja asing tanpa izin kerja. Memberikan imformasi yang tidak benar dalam mengajukan permohonan izin tinggal tetap.

3. Dikenai tindakan administrasi keimigrasian

4. Putus hubungan perkawinan orang asing yang kawin secara sah dengan warga negara Indonesia karena perceraian dan/atau atas putusan pengadilan, kecuali perkawinan yang telah berusia 10 Tahun atau lebih.

Untuk mendapatkan izin keimigrasian bagi setiap orang asing harus memenuhi syaratsyarat sebagai berikut: ${ }^{10}$

1. Memiliki surat perjalanan yang sah

2. Memiliki visa.

3. Memiliki izin masuk kembali (reentry permit).

4. Sehat, tidak menderita gangguan jiwa atau penyakit menular yang membahayakan kesehatan umum.

\footnotetext{
10 Jazim Hamidi, Charles Christian, Op.Cit., HIm. 49
} 
5. Mempunyai izin untuk masuk ke negara lain.

6. Memberikan keterangan yang benar dalam memperoleh surat perjalanan atau visa.

\section{B. Penerapan Sanksi Atas Pelanggaran Ijin Tinggal Warga Negara Asing}

Berkaitan dengan penerapan sanksi terhadap pelanggaran izin tinggal warga negara asing dapat dilakukan tindakan administratif. Undang-undang Nomor 6 Tahun 2011 Pasal 75 ayat 2 berbunyi Tindakan Administratif Keimigrasian sebagaimana dimaksud pada pasal 75 ayat (1) dapat berupa:

1. Pencantuman dalam daftar pencegahan atau penangkalan

2. Pembatasan, perubahan, atau pembatalan izin tinggal

3. Larangan untuk berada di satu atau beberapa tempat tertentu di wilayah Indonesia

4. Keharusan untuk bertempat tinggal di suatu tempat tertentu di wilayah Indonesia

5. Pengenaan biaya beban

6. Deportasi dari Wilayah Indonesia

Dalam hal tindakan keimigrasian berupa penolakan masuk ke wilayah Negara Republik Indonesia, keputusan tindakan keimigrasian oleh pejabat imigrasi di tempat pemeriksaan imigrasi dilakukan dengan menerakan tanda penolakan di paspornya. ${ }^{11}$

Maksud tindakan keimigrasian ini adalah untuk melaksanakan kebijakasanaan pengawasan di bidang keimigrasian dan membantu terlaksananya penegakan hukum di wilayah Negara Republik Indonesia baik secara preventif maupun represif. ${ }^{12}$ Hukum keimigrasian merupakan bagian dari sistem hukum yang berlaku di indonesia. Bahkan merupakan subsistem dari hukum administrasi negara. Sebagai sebuah subsistem, hukum keimigrasian di indonesia telah ada sejak jaman pemerintahan kolonial belanda. ${ }^{13}$

\footnotetext{
11 Pasal 24 ayat (1), (2) dan (3) Peraturan Pemerinta Nomor 31 Tahun 1994

12 Penjelasan Peraturan Pemerintah Nomor 31 Tahun 1994

13 M. Iman Santoso, "Persfektif Imigrasi dalam Pembangunan Ekonomi dan Ketahanan Nasional", UI Press Jakarta, 2004, hal. 1
}

Tindakan administratif yang diberikan kepada orang asing yang melanggar izin tinggal telah sesuai dengan Pasal 78 Undang-Undang Nomor 6 Tahun 2011 yang berbunyi :

1. Orang Asing pemegang Izin Tinggal yang telah berakhir masa berlakunya dan masih berada dalam Wilayah Indonesia kurang dari 60 (enam puluh) hari dari batas waktu Izin Tinggal dikenai biaya beban sesuai dengan ketentuan peraturan perundangundangan.

2. Orang Asing yang tidak membayar biaya beban sebagaimana dimaksud pada ayat (1) dikenai Tindakan Administratif Keimigrasian berupa Deportasi dan Penangkalan.

3. Orang Asing pemegang Izin Tinggal yang telah berakhir masa berlakunya dan masih berada dalam Wilayah Indonesia lebih dari 60 (enam puluh) hari dari batas waktu Izin Tinggal dikenai Tindakan Administratif Keimigrasian berupa Deportasi dan Penangkalan. Dengan demikian penegakan hukum terhadap warga negara asing (WNA) di kota Semarang telah sesuai dengan Undang-undang Nomor 6 Tahun 2011 Tentang Keimigrasian.

Pelanggaran masa izin tinggal yang telah habis (overstay) ditindak secara administratif. Tindakan administrasi diberikan kepada pelanggar izin tinggal karena memuat hal tentang pengaturan, pelayanan, perijinan dari aspek-aspek keimigrasian yaitu mengenai masuk dan keluar wilayah Indonesia.

Tindakan administratif dibagi menjadi beberapa jenis, diantaranya pencantuman dalam daftar pencegahan atau penangkalan, pembatasan, perubahan, atau pembatalan izin tinggal, larangan untuk berada di satu atau beberapa tempat tertentu di wilayah Indonesia, keharusan untuk bertempat tinggal di suatu tempat tertentu di wilayah Indonesia, pengenaan biaya beban, dan deportasi dari wilayah Indonesia (Pasal 75 Ayat 2 UndangUndang Nomor 6 Tahun 2011).

Pengenaan biaya beban disesuaikan dengan pelanggaran yang dilakukan. Pasal 78 ayat 1 menyebutkan orang asing pemegang izin tinggal yang telah berakhir masa berlakunya dan masih berada dalam Wilayah Indonesia kurang dari 60 (enam puluh) hari dari batas waktu izin tinggal dikenai biaya beban sesuai 
dengan ketentuan peraturan perundangundangan.

Tindakan administratif berupa deportasi dilakukan sesuai Pasal 78 ayat 2 dan 3 yaitu apabila orang asing tidak dapat membayar biaya beban dan orang asing pemegang izin tinggal yang telah berakhir masa berlakunya dan masih berada dalam Wilayah Indonesia lebih dari 60 (enam puluh) hari dari batas waktu Izin Tinggal dikenai tindakan administratif keimigrasian berupa deportasi dan penangkalan.

Selanjutnya tentang tindak pidana keimigrasian yang berkaitan dengan izin tinggal disebut juga sebagai penyalahgunaan izin. Meskipun dalam Undang-Undang Keimigrasian telah memberikan sanksi pidana yang tegas tetapi tindakan ini tetap dilakukan oleh warga negara asing tersebut.

Tindak pidana penyalahgunaan izin tinggal adalah suatu perbuatan/ tindakan yang bersifat melawan hukum yang dilakukan oleh WNA yang dinyatakan sebagai perbuatan yang dilarang dan diancam dengan pidana yang dilakukan dengan cara menyalahgunakan atau melakukan kegiatan yang tidak sesuai dengan maksud dan tujuan pemberian izin tinggal yang diberikan kepadanya.

Penegakan hukum terhadap tindak pidana penyalahgunaan izin tinggal di lingkungan keimigrasian dilakukan oleh Penyidik Pegawai Negeri Sipil Keimigrasian selanjutnya disebut sebagai PPNS Keimigrasian. PPNS Keimigrasian ini menurut Pasal 1 angka 8 Undang-Undang Nomor 6 Tahun 2011 tentang Keimigrasian adalah pejabat imigrasi yang diberi wewenang oleh undang-undang untuk melakukan penyidikan tindak pidana keimigrasian. PPNS Keimigrasian diberi wewenang sebagai penyidik tindak pidana keimigrasian yang dilaksanakan sesuai ketentuan undang-undang ini.

Dalam penegakan hukum terhadap pelaku tindak pidana penyalahgunaan izin tinggal PPNS Keimigrasian dapat berkoordinasi dengan lembaga penegak hukum dalam negeri yaitu Kepolisian Negara Republik Indonesia, jaksa dan hakim. Pada tingkat penyidikan koordinasi dilakukan dengan penyidik Kepolisian Negara Republik Indonesia. Koordinasi ini dilakukan agar tidak terjadi tumpang tindih penyidikan. Selain berkoordinasi dengan lembaga penegak hukum dalam negeri PPNS juga dapat melaksanakan kerja sama dengan lembaga penegak hukum negara lain sesuai dengan ketentuan peraturan perundang-undangan atau berdasarkan perjanjian internasional yang telah diakui oleh pemerintah Republik Indonesia.

Bagi pelaku tindak pidana penyalahguna izin tinggal ini dapat dijatuhkan sanksi sesuai dengan ketentuan pidana dalam UndangUndang Nomor 6 Tahun 2011 Pasal 122 huruf a yang berbunyi :

"Dipidana dengan pidana penjara paling lama 5 (lima) tahun dan pidana denda paling banyak Rp.500.000.000,00 ( lima ratus juta rupiah ) : Setiap orang asing yang dengan sengaja menyalahguna atau melakukan kegiatan yang tidak sesuai dengan maksud dan tujuan pemberian izin tinggal yang diberikan kepadanya".

Berdasarkan pasal 124 (b) Undang-Undang Nomor 6 Tahun 2011 tentang pidana melawati batas waktu tinggal (overstay), bahwa Izin Tinggalnya habis berlaku dipidana dengan pidana kurungan paling lama 3 (tiga) bulan atau pidana denda paling banyak Rp25.000.000,00 (dua puluh lima juta rupiah).

Selain dapat dijatuhi sanksi pidana, terhadap pelaku penyalahgunan izin tinggal dapat juga dijatuhkan sanksi administratif sesuai dengan pasal 75 ayat (2) UndangUndang Nomor 6 Tahun 2011 tentang Keimigrasian yaitu :

a. Pencantuman dalam daftar pencegahan atau penangkalan;

b. Pembatasan, perubahan, atau pembatalan izin tinggal;

c. Larangan untuk berada di satu atau beberapa tempat tertentu di Indonesia;

d. Keharusan untuk bertempat tinggal di suatu tempat tertentu di wilayah Indonesia yaitu di Rumah Detensi Imigrasi dan Ruang Detensi Imigrasi;

e. Pengenaan biaya beban;

f. Deportasi dari wilayah Indonesia.

Sanksi pidana sesungguhnya bersifat reaktif terhadap suatu perbuatan, sedangkan sanksi tindakan lebih bersifat antisipatif terhadap pelaku perbuatan tersebut. Fokus sanksi pidana ditujukan pada perbuatan salah yang telah dilakukan seseorang melalui pengenaan 
penderitaan agar yang bersangkutan menjadi jera. Fokus sanksi tindakan lebih terarah pada upaya memberi pertolongan pada pelaku agar ia berubah.

Selanjutnya, berdasarkan pasal 83 (b) Undang-undang nomor 6 tahun 2011 tentang keimigrasian, bawha:

(1) Pejabat Imigrasi berwenang menempatkan Orang Asing dalam Rumah Detensi Imigrasi atau Ruang Detensi Imigrasi jika Orang Asing tersebut:

a. berada di Wilayah Indonesia tanpa memiliki Izin Tinggal yang sah atau memiliki Izin Tinggal yang tidak berlaku lagi;

b. berada di Wilayah Indonesia tanpa memiliki Dokumen Perjalanan yang sah;

c. dikenai Tindakan Administratif Keimigrasian berupa pembatalan Izin Tinggal karena melakukan perbuatan yang bertentangan dengan peraturan perundang-undangan atau mengganggu keamanan dan ketertiban umum;

d. menunggu pelaksanaan Deportasi; atau

e. menunggu keberangkatan keluar Wilayah Indonesia karena ditolak pemberian Tanda Masuk.

(2) Pejabat Imigrasi dapat menempatkan Orang Asing sebagaimana dimaksud pada ayat (1) di tempat lain apabila Orang Asing tersebut sakit, akan melahirkan, atau masih anak-anak.

\section{PENUTUP}

\section{A. Kesimpulan}

1. Berkaitan dengan ketentuan tentang ijin tinggal Warga Negara Asing, pada prinsipnya keberadaan orang asing di Indonesia tetap dibatasi dalam hal kebaradaan dan kegiatannya. Hal ini dapat dilihat dalam berbagai instrumen, perizinan di bidang keimigrasian, sebagaimana ditentukan dalam UU Keimigrasian No. 6 Tahun 2011 yang mengatur mengenai beberapa jenis perizinan bagi Orang Asing di Indonesia. Pada dasarnya setiap orang asing yang berada di Indonesia wajib memiliki izin tinggal yang masih berlaku, dan ijin ini diberikan sepanjang memenuhi persyaratan keimigrasian. ljin Tinggal diberikan kepada orang asing oleh
Pejabat Imigrasi atau pejabat dinas luar negeri untuk berada di Wilayah Indonesia. Ijin tersebut terdiri atas, liin Tinggal diplomatik, ljin Tinggal dinas, ljin Tinggal kunjungan, ljin Tinggal terbatas dan ljin Tinggal tetap.

2. Bahwa tidak semua tindak pidana keimigrasian, khususnya pelanggaran ijin tinggal (overstay), dan tidak memiliki izin tinggal (illegal stay) warga negara asing dapat diterapkan sanksi pidana, karena di dalam Undang-undang Nomor 6 Tahun 2011 tentang Keimigrasian dimungkinkan diterapkan tindakan keimigrasian yang bersifat administratif non penal. Namun apabila tetap diproses melalui jalur hukum dan diterapkan sanksi pidana terhadap pelakunya, hal ini merupakan fungsi hukum pidana sebagai ultimum remedium dan sifatnya kasuistis. Tindakan administratif yang dapat diterapkan dibagi menjadi beberapa jenis, diantaranya pencantuman dalam daftar pencegahan atau penangkalan, pembatasan, perubahan, atau pembatalan izin tinggal, larangan untuk berada di satu atau beberapa tempat tertentu di wilayah Indonesia, keharusan untuk bertempat tinggal di suatu tempat tertentu di wilayah Indonesia, pengenaan biaya beban, dan deportasi dari wilayah Indonesia (Pasal 75 Ayat 2 Undang-Undang Nomor 6 Tahun 2011).

\section{B. Saran}

1. Agar wilayah Indonesia tetap aman dan tenteram diperlukan pengawasan secara terus menerus terhadap orang asing di seluruh wilayah Indonesia, berupa pengawasan terhadap orang asing yang masuk, keberadaan, kegiatan dan keluar dari wilayah Indonesia. Terhadap warga negara asing yang tidak mentaati peraturan perundang-undangan yang berlaku, termasuk yang melakukan pelanggaran ijin tinggal (overstay), harus dikenakan tindakan hukum.

2. Diharapkan kepada Kementerian Hukum dan HAM, khusunya Direktorat Jenderal Imigrasi dan Kantor Wilayah Imigrasi untuk lebih mengutamakan dan 
meningkatkan kedisiplinan, integritas dan kinerja secara optimal dalam melaksanakan peran dan fungsi dalam pelaksanaan pengawasan dan penindakan terhadap pelanggaran hukum warga negara asing. Faktor berikutnya yaitu sarana atau fasilitas yang mendukung penegakan hukum, mencakup sumberdaya manusia yang berpendidikan dan terampil, organisasi yang baik, peralatan yang memadai, keuangan yang cukup, dan seterusnya.

\section{DAFTAR PUSTAKA}

Buku :

Abdullah Sjahriful, Memperkenalkan Hukum Keimigrasian, Ghalia, Jakarta 1993.

Antonius Cahyadi dan E. Fernando M. Manullang, Pengantar Ke Filsafat Hukum, Kencana Prenada Media Group, Jakarta, 2007.

Arief Barda Nawawi, Kapita Selekta Hukum Pidana, PT. Citra Aditya Bakti, Bandung, 2003.

Ateng Syarifudin, Perizinan Untuk Berbagi Kegiatan, Makalah tidak dipublikasikan.

Bhakti Yudha, Hukum Internasional: Bunga Rampai, Alumni, Bandung 2003.

Hamidi Jazim, Charles Christian, Hukum Keimigrasian Bagi Orang Indonesia, Sinar Grafika, Jakarta, 2015.

"Hukum Keimigrasian Dalam Sistem Hukum Nasional", disampaikan dalam Rapat Kerja Nasional Keimigrasian, Jakarta, 14 Januari 2000.

HR Ridwan, Hukum Administrasi Negara, PT. RajaGrafindo, Jakarta

Moelijanto, Asas-Asas Hukum Pidana, Rineka Cipta, 2008

Manan Bagir, 1995, Ketentuan-Ketentuan Mengenai Pengaturan Penyelenggara Hak Kemerdekaan Berkumpul Ditinjau Dari Perspektif Uud 1945, Makalah Tidak Dipublikasikan, Jakarta.

M.M Van Praag, Algemeen Nederlands Administratief Recht, Juridische Boekhandel en Uitgeverij A. Jongbloed \& Zoon, S Gravenhage, 1950.

M. Imam Santoso, "Persfektif Imigrasi dalam Pembangunan Ekonomi dan Ketahanan Nasional", UI Press Jakarta, 2004.

M. Sholehuddin, Sistem Sanksi Dalam Hukum Pidana Ide Dasar Double Track System dan Implementasinya, PT. RajaGrafindo Persada, 2003.
Misbach dkk, Pengantar Ilmu Hukum Internasional, Universitas Negeri Jember, 1980.

Philipus M. Hadjon dkk, Pengantar Hukum Administrasi Internasional Indonesia, cet. Ke-X, Gajah Mada University Press, Yogyakarta.

Projodikno Wirjono, Asas-Asas Hukum Pidana di Indonesia, Refika Aditama, Bandung, 2003.

Sihar Sihombing, Hukum Imigrasi, Nuansa Mulia, Bandung, 2009.

Soekanto Soerjono dan Sri Mamudji, Penelitian Hukum Normatif, Rajawali, Jakarta 1985.

Schwarzenberger, I Manual Of International Law, Stevens and Sons, 6th ed, London.

Soeroso R. Pengantar IImu Hukum, cet ke-8, Sinar Grafika, Jakarta, 2006.

Soerjono Soekanto, Teori Yang Murni Tentang Hukum, PT. Alumni, Bandung, (selanjutnya disingkat Soerjono Soekanto II)

Samsul Ranli dan Fahrurazi, Bacaan Wajib Swakelola Pengadaan Barang/Jasa, Visimedia Pustaka, Jakarta, 2014.

T.S.G.Mulia dan K.A.H.Hidding, Ensiklopedia Indonesia, Jilid II, W.Van Hoeve, Bandung-Gravenhage, 1957.

Wahyudin Ukun, Deportasi sebagai Instrumen Penegakan Hukum dan Kedaulatan Negera di Bidang Keimigrasian, PT. Adi Kencana Aji, Jakarta 2004.

Peraturan Perundang-undangan.

Undang-Undang Nomor 6 Tahun 2011 Tentang Keimigrasian.

Peraturan Pemerintah Nomor. 31 Tahun 1994 Tentang Pengawasan Orang Asing.

\section{Sumber Lain}

Kamus Besar Bahasa Indonesia, Balai fustaka, Jakarta, 1995.

\section{Website}

"http;//kbri-astana.kz/id/visa-95\%7C96.html, di akses pada tanggal 16 Januari 2020. 